\title{
Estimation of Crop Evapotranspiration Using Satellite Remote Sensing-Based Vegetation Index
}

\author{
Arturo Reyes-González $\mathbb{D}^{1},{ }^{1,2}$ Jeppe Kjaersgaard, ${ }^{3}$ Todd Trooien, ${ }^{1}$ \\ Christopher Hay, ${ }^{4}$ and Laurent Ahiablame ${ }^{1}$ \\ ${ }^{1}$ Department of Agricultural and Biosystems Engineering, South Dakota State University, Brookings, SD, USA \\ ${ }^{2}$ Instituto Nacional de Investigaciones Agrícolas, Forestales y Pecuarias (INIFAP), Blvd. Prof. José Santos Valdez, \\ No. 1200 Pte, Col. Centro, Matamoros, COAH, Mexico \\ ${ }^{3}$ Minnesota Department of Agriculture, St. Paul, MN, USA \\ ${ }^{4}$ Iowa Soybean Association, Ankeny, IA, USA
}

Correspondence should be addressed to Arturo Reyes-González; reyes.arturo@inifap.gob.mx

Received 25 August 2017; Accepted 26 December 2017; Published 1 February 2018

Academic Editor: Jan Friesen

Copyright (C) 2018 Arturo Reyes-González et al. This is an open access article distributed under the Creative Commons Attribution License, which permits unrestricted use, distribution, and reproduction in any medium, provided the original work is properly cited.

\begin{abstract}
Irrigation water is limited and scarce in many areas of the world, including Comarca Lagunera, Mexico. Thus better estimations of irrigation water requirements are essential to conserve water. The general objective was to estimate crop water demands or crop evapotranspiration $\left(\mathrm{ET}_{\mathrm{c}}\right)$ at different scales using satellite remote sensing-based vegetation index. The study was carried out in northern Mexico (Comarca Lagunera) during four growing seasons. Six, eleven, three, and seven clear Landsat images were acquired for 2013, 2014, 2015, and 2016, respectively, for the analysis. The results showed that ET $\mathrm{E}_{c}$ was low at initial and early development stages, while $\mathrm{ET}_{\mathrm{c}}$ was high during mid-season and harvest stages. These results are not new but give us confidence in the rest of our $\mathrm{ET}_{c}$ results. Daily $\mathrm{ET}_{c}$ maps helped to explain the variability of crop water use during the growing season. Based on the results we can conclude that $\mathrm{ET}_{\mathrm{c}}$ maps developed from remotely sensed multispectral vegetation indices are a useful tool for quantifying crop water consumption at regional and field scales. Using $\mathrm{ET}_{\mathrm{c}}$ maps at the field scale, farmers can supply appropriate amounts of irrigation water corresponding to each growth stage, leading to water conservation.
\end{abstract}

\section{Introduction}

Irrigation water is limited and scarce in many areas of the world. Agriculture is the major consumer of fresh water $[1,2]$, but it is not necessarily used efficiently due to farmers supplying more water than is consumed by the crop. Thus, better estimation of irrigation water requirements is essential to use water efficiently so water is available for use in the future. To achieve water conservation, it is necessary that farmers adopt new technologies for estimating crop water demands more accurately.

Crop evapotranspiration $\left(\mathrm{ET}_{\mathrm{c}}\right)$ represents crop water requirement and is affected by weather and actual crop conditions $[3,4]$. A useful method to estimate $\mathrm{ET}_{\mathrm{c}}$ or crop water requirements is to multiply reference evapotranspiration $\left(\mathrm{ET}_{\mathrm{r}}\right)$ by a crop coefficient $\left(K_{\mathrm{c}}\right)($ see $(1)) . \mathrm{ET}_{\mathrm{r}}$ is estimated based on meteorological information (e.g., solar radiation, air temperature, wind, and air vapor pressure deficit) from a local weather station. The Penman-Monteith equation has been advanced as the standard method for estimating reference ET $[5,6] . K_{c}$ is typically taken from literature values and is affected by crop variety and growth stage [5-7]. $\mathrm{ET}_{\mathrm{c}}$ has been estimated or measured using other methods, for example, weighing lysimeters, evaporation pan, soil water balance, atmometer, Bowen Ratio Energy Balance System (BREBS), and Eddy Covariance (EC). However, these methods are recognized as the point-based measurements. Satellite-based remote sensing is an alternative to estimate crop water requirement and its spatial and temporal distribution on a field-by-field basis at a regional scale. These remote sensingbased methods have been shown to be accurate [8-11]:

$$
\mathrm{ET}_{\mathrm{c}}=\mathrm{ET}_{\mathrm{r}} \times K_{\mathrm{c}} .
$$




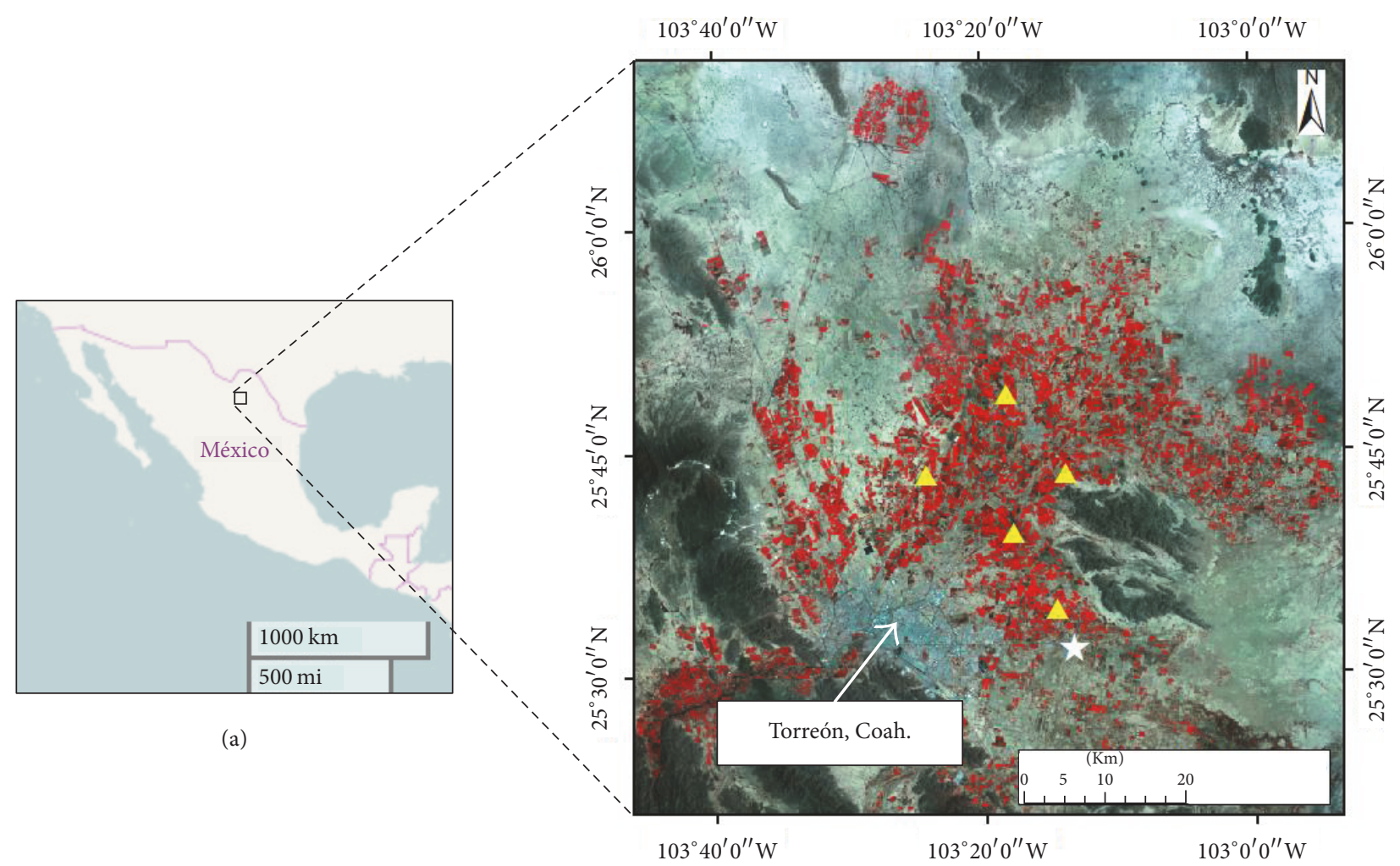

(b)

Figure 1: Location of the study area at northern Mexico (a). The subset of the area of interest, Landsat with false color composite (bands 4, $3,2)$; the yellow triangles denote five locations where we selected the corn fields and the white star indicates weather station (b).

Remote sensing is a technology that can estimate $\mathrm{ET}_{\mathrm{c}}$ at regional and local scale in less time and with less cost $[9,10]$. Remote sensing can also estimate crop coefficients based on spectral reflectance of vegetation indices (VIs) [5, 12]. The normalized difference vegetation index (NDVI) is the most common VIs [13]. NDVI takes into account the reflectance of red and near-infrared wavebands [14], where red waveband is strongly absorbed by chlorophyll in leaves of the top layers, while near-infrared wavebands is reflected by the mesophyll structure in leaves, penetrating into deeper leaf layers in a healthy vegetation $[15,16]$. High values of NDVI are related to healthy and dense vegetation, which presents high reflectance values in the NIR waveband and low reflectance values in the red waveband [17]. Crop coefficients generated from VIs determine $\mathrm{ET}_{\mathrm{c}}$ better than a tabulated $K_{\mathrm{c}}$ because it represents the actual crop growth conditions and capture the spatial variability among different fields $[2,18,19]$.

Several studies have used multispectral vegetation indices derived from remote sensing to estimate $K_{\mathrm{c}}$ values on agricultural crops including corn crop, for example, in [20-31]. Crop coefficients derived from remotely sensed vegetation index also have used to generate local and regional $\mathrm{ET}_{\mathrm{c}}$ maps $[2,32-$ 34]; however, in northern Mexico, $\mathrm{ET}_{\mathrm{c}}$ maps using satellite remote sensing-based vegetation index remain unexplored.

The objectives of this study were to (1) calculate NDVI values for each corn field for each growing season, (2) develop a simple linear regression model between NDVI derived from satellite-based remote sensing and tabulated $K_{c}$ obtained of alfalfa-based crop coefficient from ASCE Manual 70 , (3) generate $K_{\mathrm{c}}$ maps using the linear regression equation obtained between NDVI and $K_{c}$ values, and (4) create $\mathrm{ET}_{c}$ maps with high spatial resolution at regional and field scales.

\section{Materials and Methods}

2.1. Study Area. The study was carried out in northern Mexico (Comarca Lagunera) during four growing seasons. Comarca Lagunera had an average latitude of $25^{\circ} 40^{\prime} \mathrm{N}$ and longitude of $103^{\circ} 18^{\prime} \mathrm{W}$ and elevation of $1115 \mathrm{~m}$ above mean sea level (Figure 1). In Comarca Lagunera, forage crops (alfalfa, corn, sorghum, and oat (planted in the winter season)) occupied more than $75 \%$ of the total irrigated area [35]. Silage corn is the most important crop after alfalfa in this region. Five silage corn fields in each growing season were selected for NDVI calculations. The corn fields were irrigated using surface irrigation systems. The plant population density was 78,000 plants ha ${ }^{-1}$. Silage corn is typically planted from late March to early April and chopped for silage from late July to early August, depending on the crop variety. The corn fields selected ranged between 10 and 20 hectares in size. The soil texture for this region is clay loam soil. The mean annual maximum temperature is $28^{\circ} \mathrm{C}$, minimum $13^{\circ} \mathrm{C}$, and mean $21^{\circ} \mathrm{C}$ [36]. The mean annual precipitation is $200 \mathrm{~mm}$, while the annual potential evapotranspiration is $2,000 \mathrm{~mm}$ [37]. 
TABLE 1: The year, acquisition dates, day after planting (DAP), Landsat satellite, and path/row for 2013, 2014, 2015, and 2016 growing seasons.

\begin{tabular}{|c|c|c|c|c|}
\hline Year & Acquisition Dates & DAP & Satellite & Path/Row \\
\hline \multirow{6}{*}{2013} & April 14 & 10 & Landsat 8 & $30 / 42$ \\
\hline & April 22 & 18 & Landsat 7 & $30 / 42$ \\
\hline & April 30 & 26 & Landsat 8 & $30 / 42$ \\
\hline & May 16 & 42 & Landsat 8 & $30 / 42$ \\
\hline & June 9 & 66 & Landsat 7 & $30 / 42$ \\
\hline & June 17 & 74 & Landsat 8 & $30 / 42$ \\
\hline \multirow{11}{*}{2014} & April 17 & 8 & Landsat 8 & $30 / 42$ \\
\hline & May 3 & 24 & Landsat 8 & $30 / 42$ \\
\hline & May 11 & 32 & Landsat 7 & $30 / 42$ \\
\hline & May 19 & 40 & Landsat 8 & $30 / 42$ \\
\hline & May 27 & 48 & Landsat 7 & $30 / 42$ \\
\hline & June 4 & 56 & Landsat 8 & $30 / 42$ \\
\hline & June 12 & 64 & Landsat 7 & $30 / 42$ \\
\hline & June 28 & 80 & Landsat 7 & $30 / 42$ \\
\hline & July 6 & 88 & Landsat 8 & $30 / 42$ \\
\hline & July 14 & 96 & Landsat 7 & $30 / 42$ \\
\hline & July 22 & 104 & Landsat 8 & $30 / 42$ \\
\hline \multirow{3}{*}{2015} & April 28 & 22 & Landsat 7 & $30 / 42$ \\
\hline & May 30 & 54 & Landsat 7 & $30 / 42$ \\
\hline & July 17 & 102 & Landsat 7 & $30 / 42$ \\
\hline \multirow{7}{*}{2016} & April 14 & 8 & Landsat 7 & $30 / 42$ \\
\hline & May 16 & 40 & Landsat 7 & $30 / 42$ \\
\hline & June 9 & 64 & Landsat 8 & $30 / 42$ \\
\hline & June 25 & 80 & Landsat 8 & $30 / 42$ \\
\hline & July 3 & 88 & Landsat 7 & $30 / 42$ \\
\hline & July 11 & 96 & Landsat 8 & $30 / 42$ \\
\hline & July 19 & 104 & Landsat 7 & $30 / 42$ \\
\hline
\end{tabular}

2.2. Landsat Images. Clear sky images from Landsat 7 Enhanced Thematic Mapper Plus (ETM+) and Landsat 8 Operational Land Imager (OLI) and Thermal Infrared Sensor (TIRS) (Path 30, Row 42) were used to estimate NDVI, $K_{c}$, and $\mathrm{ET}_{\mathrm{c}}$ values. The images were downloaded from the United States Geological Survey (USGS) EROS Datacenter. EROS performed the atmospheric corrections on the images. Also the wedge-shaped gaps appearing within the Landsat 7 images as a result of the SLC-off issue were removed using the Imagine built-in focal analysis tool [11]. Six, eleven, three, and seven clear Landsat images were acquired for 2013, 2014, 2015, and 2016, respectively (Table 1). The satellite images were processed using the Model Maker tool of ERDAS Imagine Software.

2.3. Pixel Selection. Ten pixels for each corn field and each season were selected and extracted from NDVI maps. The pixels were located in the center of each corn field for each overpass date during the four growing seasons. The same pixels were observed throughout the corn growing season. We assumed that the pixels are representative of the entire corn field. All corn fields had flat terrain. The number of pixels per year is presented in Table 2 .
TABLE 2: The year and number of pixels selected throughout the growing season.

\begin{tabular}{lc}
\hline Year & Number of pixels \\
\hline 2013 & 300 \\
2014 & 550 \\
2015 & 150 \\
2016 & 350 \\
\hline
\end{tabular}

2.4. NDVI Calculations. The NDVI is the difference between near-infrared (NIR) and red waveband reflectances divided by their sum [13]. NDVI values range between -1 and +1 , where water presents negative values and dense canopy presents high positive values [17, 38, 39]. The NDVI was calculated for each overpass date and for each growing season using Model Maker tool of ERDAS Imagine Software as shown in the next equations:

For Landsat 7, NDVI was calculated as follows:

$$
\mathrm{NDVI}=\frac{\left(\mathrm{NIR}_{\text {band } 4}-\operatorname{Red}_{\text {band 3 }}\right)}{\left(\mathrm{NIR}_{\text {band } 4}+\operatorname{Red}_{\text {band 3 }}\right)}
$$




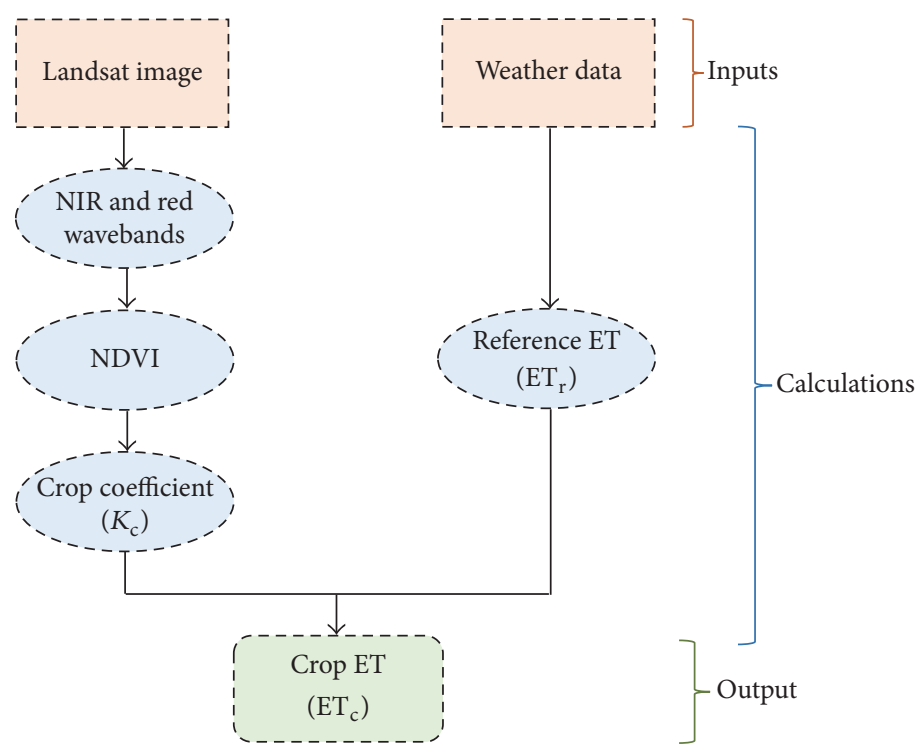

FIGURE 2: Flowchart of crop evapotranspiration estimation using vegetation index method.

For Landsat 8, NDVI was calculated as follows:

$$
\text { NDVI }=\frac{\left(\operatorname{NIR}_{\text {band } 5}-\operatorname{Red}_{\text {band } 4}\right)}{\left(\operatorname{NIR}_{\text {band } 5}+\operatorname{Red}_{\text {band } 4}\right)},
$$

where NIR $_{\text {band }}$ and Red $_{\text {band }}$ are the near-infrared and red wavebands, respectively.

Reyes-González et al. [40] made some comparisons of NDVI derived from satellite remote sensing and derived from GreenSeeker in the Comarca Lagunera, Mexico. The results showed that the NDVI values derived from satellite were within $95 \%$ of the in situ values (data not shown).

2.5. Crop Coefficient $\left(K_{c}\right)$ Values from Manual 70. The $K_{c}$ values were taken from ASCE Manual 70 (Appendix E) [7] and were adjusted according to different corn growth stages throughout the growing season. For $K_{\mathrm{c}}$ estimations the ASCE Manual 70 divides the growing season into two periods, namely, percent of time from planting to effective cover and days after effective cover to harvest. The effective cover and harvest of corn in our study occurred around 55 and 105 DAP, respectively, based on the crop phenology.

2.6. Relationship between NDVI and $K_{c}$ and $K_{c}$ Maps Development. The relationships between NDVI derived from Landsat images and tabulated $K_{c}$ 's values obtained from ASCE Manual 70 (Appendix E) [7], corresponding to each satellite overpass date for 2013, 2014, 2015, and 2016 corn growing seasons, were established. These relationships were used to generate a single linear regression equation for entire period of study.

2.7. Reference Evapotranspiration $\left(E T_{r}\right)$ Calculations. The meteorological information was taken from an automated weather station. The weather station was located at the National Institute of Forestry, Agriculture, and Livestock Research (INIFAP), Matamoros, Coahuila, Mexico (Figure 1).
The $\mathrm{ET}_{\mathrm{r}}$ values were taken from the weather station, where $\mathrm{ET}_{\mathrm{r}}$ was calculated using the Penman-Monteith equation $[5,41]$.

2.8. Crop Evapotranspiration $\left(E T_{c}\right)$ Maps. The $K_{c}$ values from the $K_{\mathrm{c}}$ maps were multiplied by $\mathrm{ET}_{\mathrm{r}}$ (see (1)) to create $\mathrm{ET}_{\mathrm{c}}$ maps with high spectral resolution $(30 \mathrm{~m})$ for 2014 growing season, using Model Maker tool of ERDAS Imagine Software and ArcGIS version 10.3.1. The $\mathrm{ET}_{\mathrm{c}}$ maps are generated to monitor the spatial distribution and temporal evolution of the crop water requirements during the growing season.

2.9. Flowchart of ET $T_{c}$ Estimation. A summary of $\mathrm{ET}_{\mathrm{c}}$ estimation using satellite remote sensing-based vegetation index is shown in Figure 2. The Landsat images and weather data are the two major inputs parameters in the vegetation index method.

\section{Results and Discussion}

3.1. NDVI Curves. The NDVI average values (10 pixels) selected and extracted from NDVI maps for five corn fields and for different corn growing seasons are shown in Figure 3. The figures show similar NDVI curves for 2014 and 2016, while, for 2013 and 2015, the curves are incomplete due to lack of clear sky images during the growing seasons. In general, NDVI values at initial stage were low around 0.15 in early April (DAP 8). Then the NDVI values increase as the crop develops reaching its maximum value $(0.8)$ at mid-season stage followed by plateau from late May to middle July (DAP 55-95). At the end of the season the NDVI values are slightly decreasing $(\sim 0.7)$ by the end of July (DAP 105). Several researchers reported similar seasonal NDVI curves for corn (e.g., [17, 20, 24, 30, 42-47]). All NDVI curves developed by these researchers showed low values at early stages, then increasing at mid-season stages and then slightly declining at late stages. However, Thomason et al. [44] reported that 

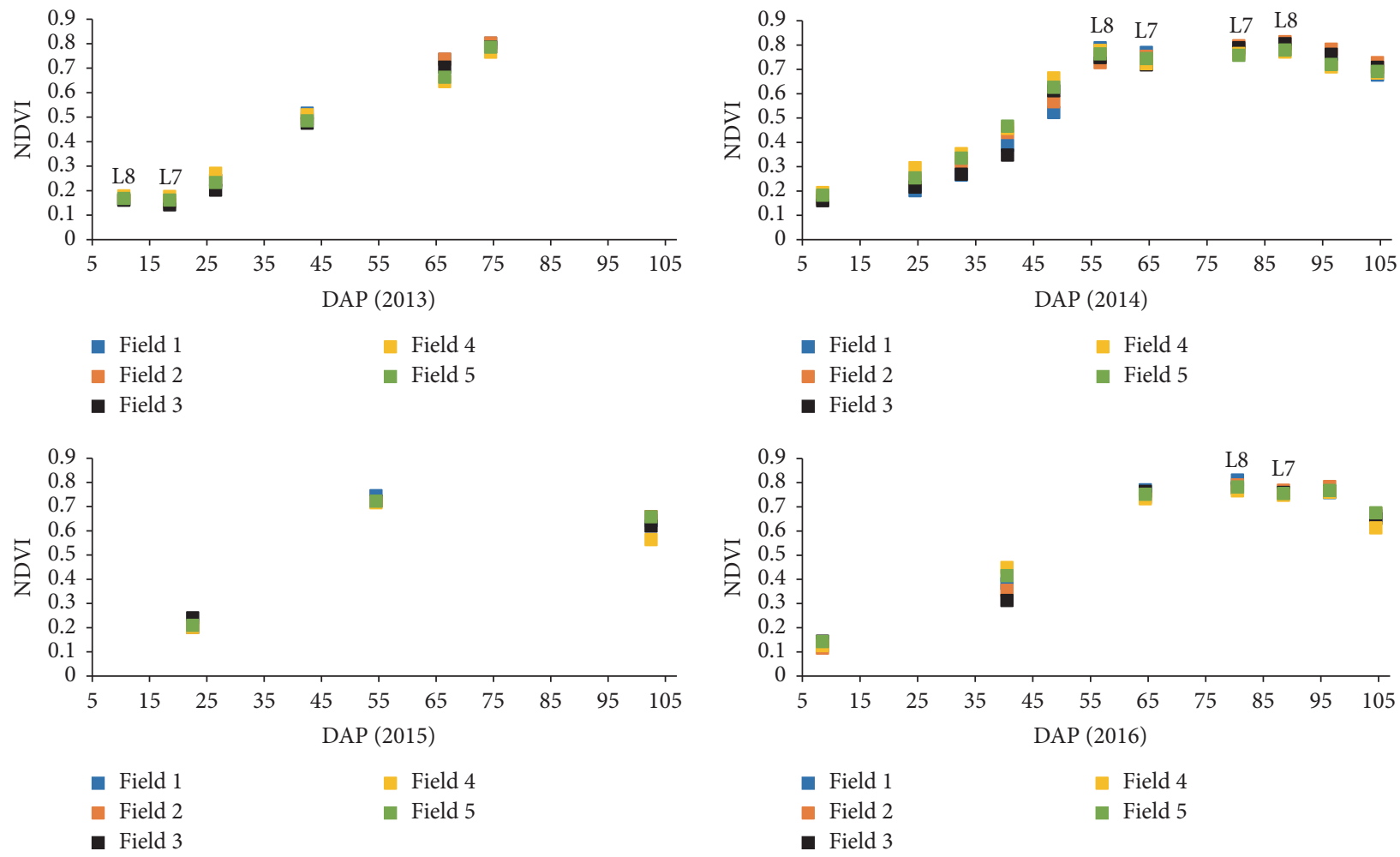

FIgURE 3: Seasonal evolution of NDVI at five corn fields for 2013, 2014, 2015, and 2016 growing seasons in northern Mexico.

NDVI curves of forage corn gradually increased from initial to mid-season and then remained constant until the end of the season.

In this study, the NDVI values derived from Landsat 8 (L8) were greater than NDVI values derived from Landsat 7 (L7) in mid-season (Figure 3 (2014 and 2016)) and early stages (Figure 3 (2013)). The differences between L8 and L7 ranged from 0.03 to 0.09 (data not shown). Those differences are in agreement with values reported by Flood [48] (0.04) and Ke et al. [49] (0.06), but greater than reported by Roy et al. [50] (0.02). The difference between L8 and L7 was because L8 has a narrower near-infrared waveband ( $\mathrm{L} 7=0.77-0.90 \mu \mathrm{m}$, $\mathrm{L} 8=0.85-0.88 \mu \mathrm{m}$ ), higher signal to noise ratio, and higher 12 -bit radiometric resolution [48, 49, 51, 52]. These features provide more precise measurements that are less influenced by atmospheric conditions and more sensitive to surface reflectance $[48,49,52]$. Although the comparison of NDVI between L8 and L7 was not an objective of this study, it is important to mention that inconsistent or unreliable values of NDVI can produce poor estimates of crop evapotranspiration [49].

3.2. Relationship between NDVI and $K_{c}$. The NDVI values were taken from NDVI maps generated as an output using Landsat 7 and Landsat 8, while $K_{\mathrm{c}}$ values were taken from ASCE Manual 70 (Appendix E) table for 2013, 2014, 2015, and 2016 corn growing seasons. Figure 4 shows the relationship between NDVI of five corn fields and tabulated $K_{c}$ values for four growing seasons. Strong relationships were observed for 2013 and 2015 growing seasons, with $r^{2}$ equal to 0.99 , whereas, for 2014 and 2016, $r^{2}$ was equal to 0.96 . The slightly low values of $r^{2}$ found in 2014 and 2016 seasons, probably was due to major numbers of NDVI values, where some of them were lower than $K_{\mathrm{c}}$ values, especially in development growth stage. Similar values of coefficients of determination (0.99) between NDVI and $K_{c}$ for corn crop were found by Rocha et al. [53] and Reyes-González et al. [54] but low coefficients were reported by Sing and Irmak [45], Kamble et al. [30], and Toureiro et al. [17], who reported values of $r^{2}$ to be equal to $0.83,0.81$, and 0.82 , respectively.

The NDVI computed from Landsat images and $K_{c}$ obtained from Appendix E of ASCE Manual 70 were used to develop the linear regression equations for 2013, 2014, 2015, and 2016 growing seasons (Figure 4). Those linear regressions were similar to the linear equations of corn reported by other researchers; for example, in [20,53-55], all these authors used alfalfa-reference crop coefficient and NDVI values for generating linear regression equations.

The linear regression equations for the four years were compared using the $t$-test method to test statistical difference between two independent regressions [56]. Table 3 shows the results of all comparisons, where all $t$ values were less than tabulated $t$ values, which means that there were no statistical differences between linear regression equations. Based on these results all data from the four years were pooled and a single linear equation was generated (Figure 5). This linear equation was used to create $K_{\mathrm{c}}$ maps for 2014 growing season (Figure 6).

3.3. $K_{c}$ Maps and $K_{c}$ Curve. Previous empirical linear equation between NDVI and $K_{c}$ was used to generate $K_{c}$ maps using Landsat images processed in ERDAS Imagine Software 
2013

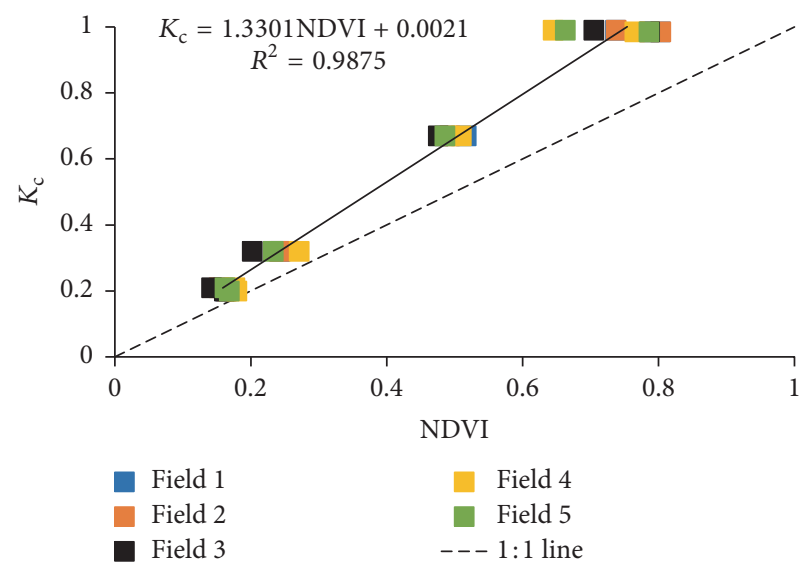

2015

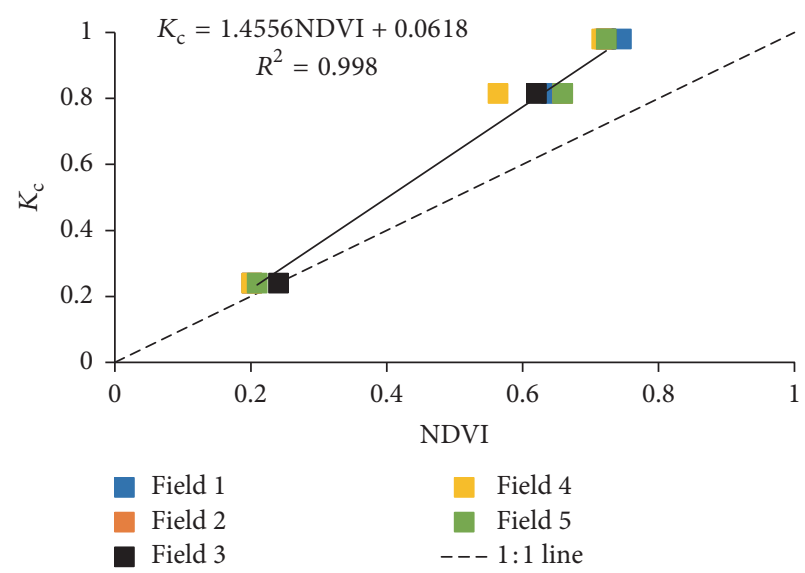

2014

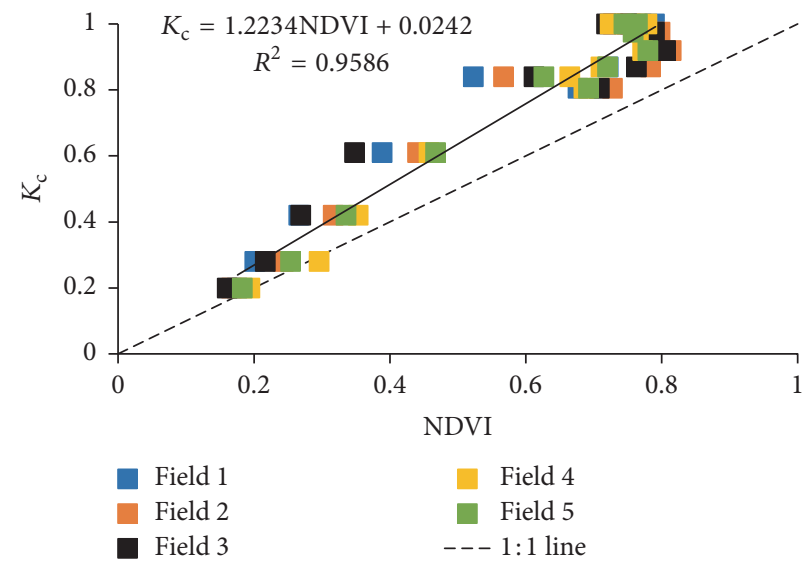

2016

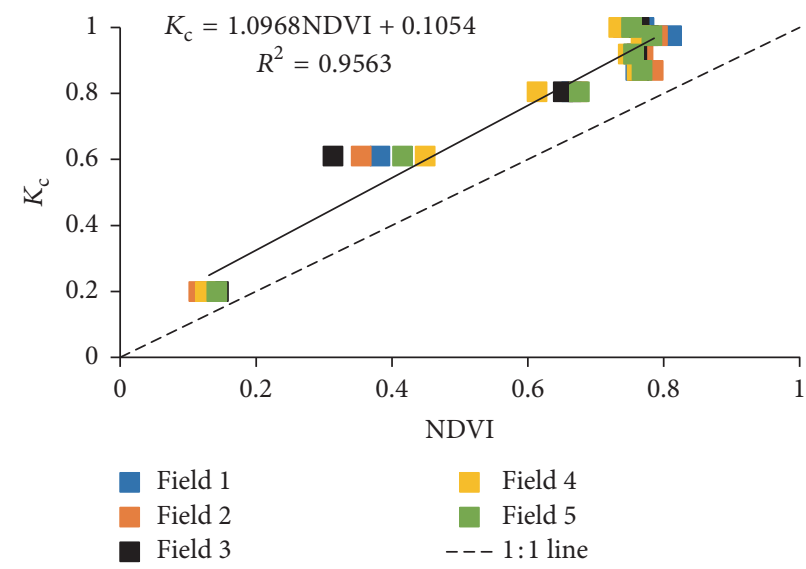

FIgURE 4: Linear relationship between NDVI derived from NDVI maps and $K_{\mathrm{c}}$ from ASCE Manual 70 for four growing seasons. The dashed line indicates the $1: 1$ line.

TABLE 3: Comparisons between linear regression equations using the $t$-test method.

\begin{tabular}{lcc}
\hline Compared years & $t$ value & $t$ from table \\
\hline 2013 to 2014 & 1.14 & 2.16 \\
2013 to 2015 & 0.96 & 2.57 \\
2013 to 2016 & 2.13 & 2.26 \\
2014 to 2015 & 1.53 & 2.22 \\
2014 to 2016 & 1.08 & 2.14 \\
2015 to 2016 & 2.31 & 2.44 \\
\hline
\end{tabular}

(Model Maker) for the 2014 growing season. Figure 6 shows spatial and temporal variability of $K_{\mathrm{c}}$ values throughout the 2014 growing season. The $K_{\mathrm{c}}$ maps showed low $K_{\mathrm{c}}$ values early in the growing season (DAP 8) (light blue-green color) and gradually increase at mid-season stage (DAP 56), where plateau remains until harvest (DAP 105) (brown color). Similar $K_{c}$ maps for corn were developed by Sing and Irmak [45], Irmak et al. [57], Rocha et al. [53], and Reyes-González et al. [54], who reported maps of daily spatial distribution of $K_{c}$ for six, four, seven, and four overpass dates, respectively.

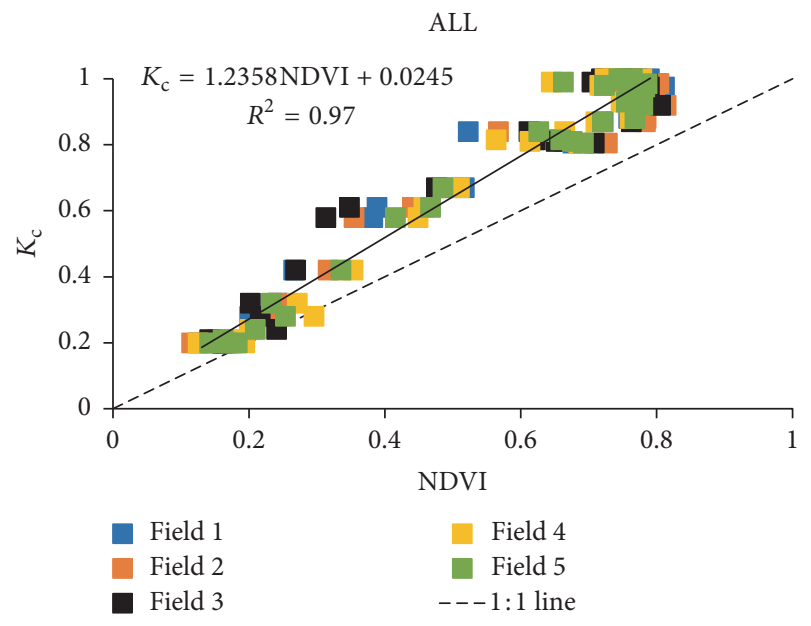

FIGURE 5: Linear relationship between NDVI and $K_{c}$ for all data. The dashed line indicates the 1:1 line.

The weather during our 2014 season resulted in usable images for nearly every satellite overpass, on 8-day intervals. These 

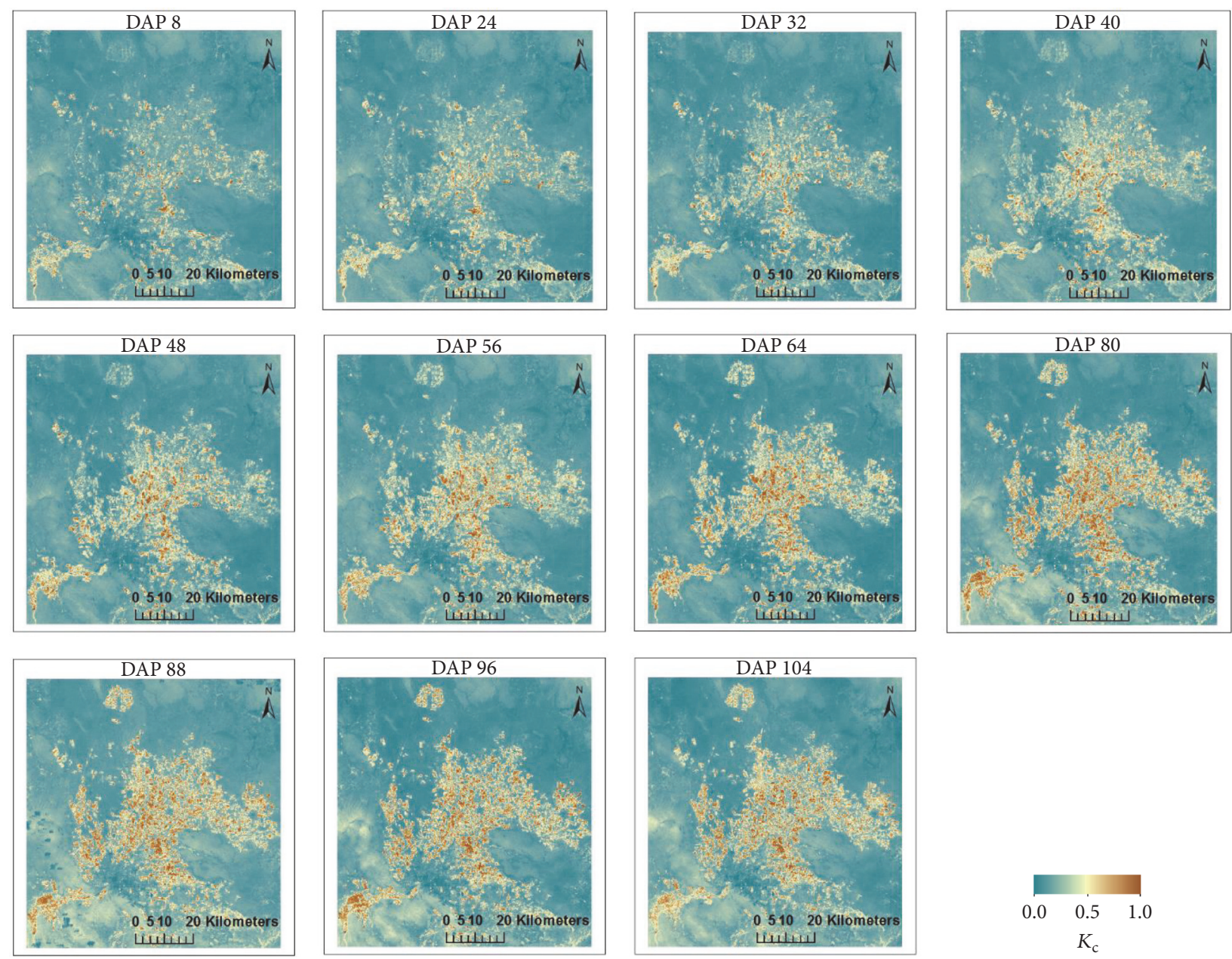

FIGURE 6: Spatial and temporal evolution of $K_{\mathrm{c}}$ generated with ERDAS Imagine Software (Model Maker) and ArcGIS version 10.3.1 during the 2014 growing season in northern Mexico.

$K_{\mathrm{c}}$ maps show how the $K_{\mathrm{c}}$ values increase (from 0.2 to 1.0 ) as the silage crop develops.

The $K_{\mathrm{c}}$ values obtained from $K_{\mathrm{c}}$ maps based on the average of ten selected pixels within each of five corn fields for each overpass date throughout the 2014 growing season is shown in Figure 7. In general, the minimum $K_{c}$ value (0.24) was presented in early season, while the maximum $K_{c}$ value (1.00) was presented in the mid-season stage. The standard deviation (vertical bars) values of $K_{c}$ were lower than 0.07 throughout the growing season (Figure 7), this means that planting dates, management practice, and maturity dates among corn fields did not affect too much the $K_{\mathrm{c}}$ values during the season.

The relationship between $K_{\mathrm{c}}$ calculated from $K_{\mathrm{c}}$ maps and $K_{\mathrm{c}}$ from tables is shown in Figure 8. A strong relationship was found with $r^{2}=0.96$. This means that $K_{c}$ values derived from vegetation index $\left(K_{\mathrm{c}}\right.$ calculated) can be a robust parameter to calculate actual crop evapotranspiration. The main difference between $K_{c}$ calculated and $K_{c}$ tabulated is that the $K_{\mathrm{c}}$ tabulated comes from well-water reference crop (e.g., alfalfa), whereas $K_{c}$ calculated comes from the actual crop growth conditions, where some $K_{c}$ values derived from

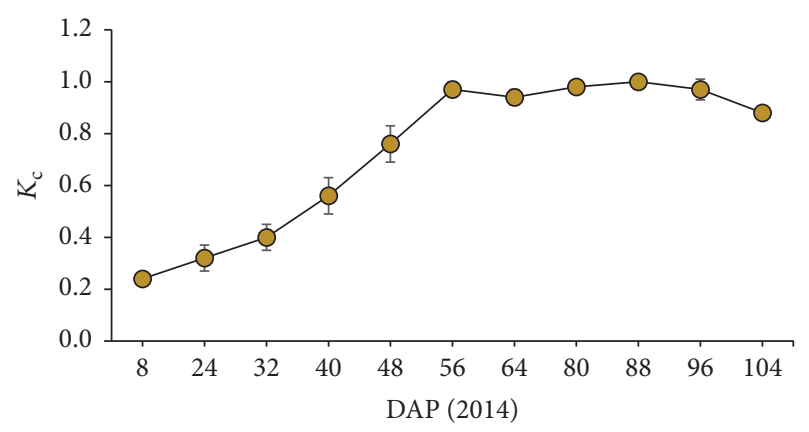

FIgURE 7: Crop coefficient curve of corn throughout the 2014 growing season. Vertical bars represent standard deviation values.

reflectance of vegetation were reduced by soil water content. Similar results were reported by Singh and Irmak [45] and Kamble et al. [30]. They found that limited moisture content decreased $K_{\mathrm{c}}$ values. Those low $K_{\mathrm{c}}$ values occurred around 15 days previous to start the mid-season stage. In our study the little difference between $K_{\mathrm{c}}$ calculated and $K_{\mathrm{c}}$ tabulated was 


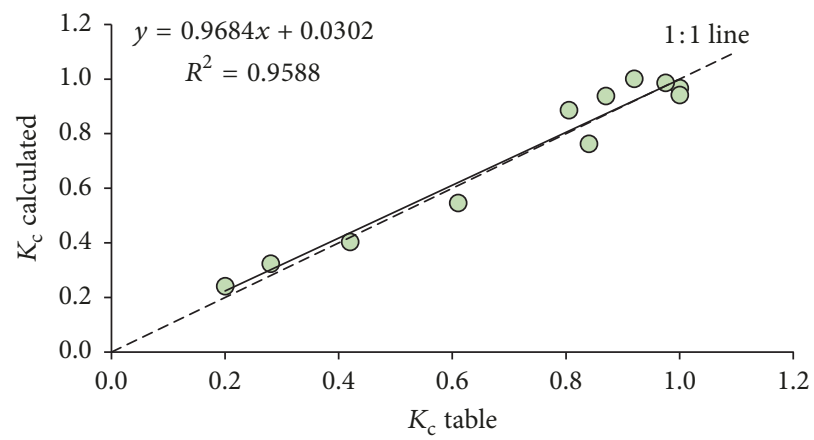

Figure 8: Relationship between $K_{\mathrm{c}}$ calculated and $K_{\mathrm{c}}$ tabulated for corn during 2014 growing season. The dashed line indicates the $1: 1$ line.
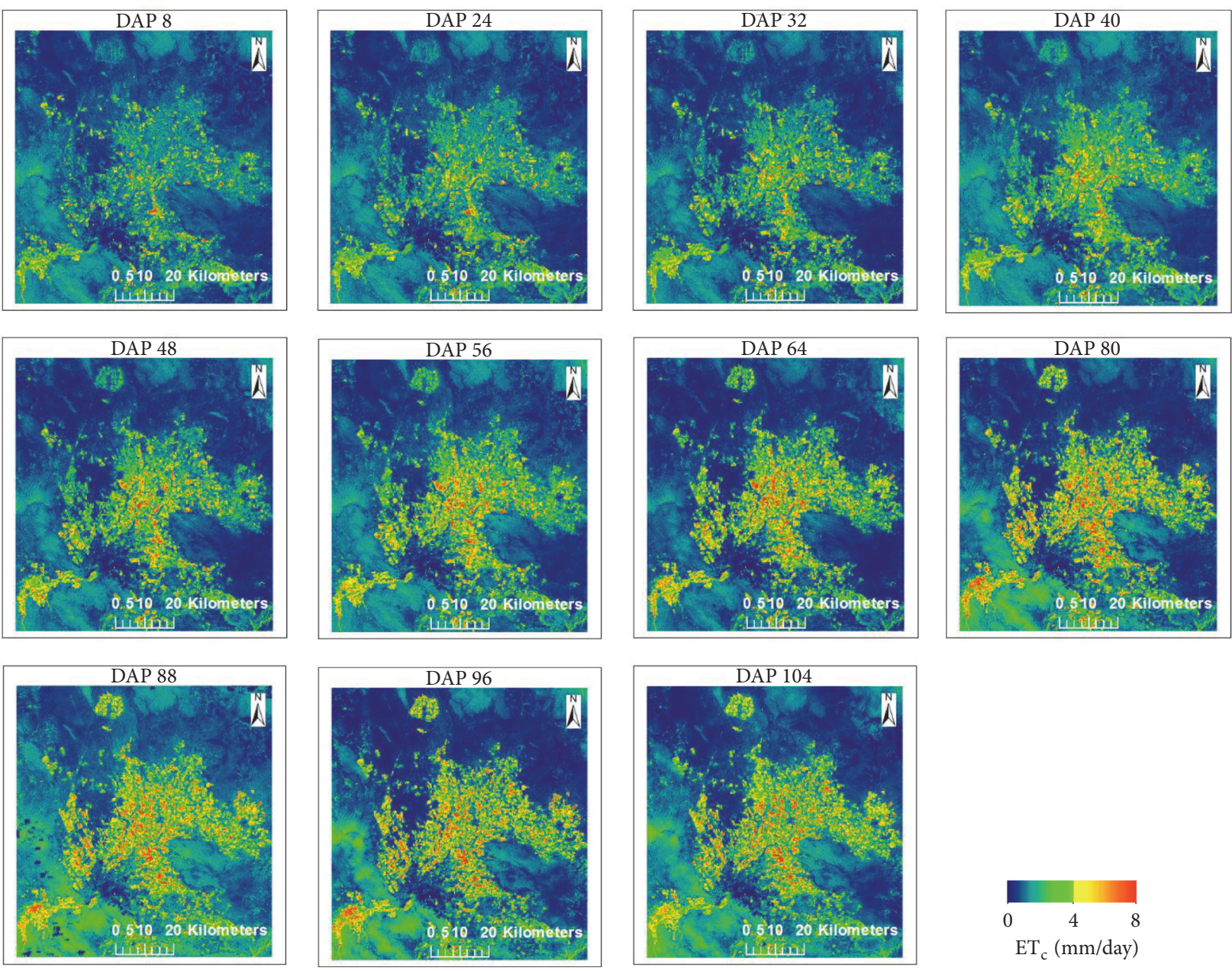

FIGURE 9: Spatial and temporal ET ${ }_{c}$ maps generated with ERDAS Imagine Software (Model Maker) and ArcGIS version 10.3.1 for 2014 growing season in northern Mexico.

found in the development growth stage (DAP 40-48) when limited soil moisture content was presented.

3.4. $E T_{c}$ Maps and $E T_{c}$ Values. $E T_{c}$ maps of $30 \mathrm{~m}$ resolution were generated as an output of $K_{\mathrm{c}}$ maps multiplied by $\mathrm{ET}_{\mathrm{r}}$ values for corresponding day using ERDAS Imagine Software (Model Maker) for 2014 growing season (Figure 9). The $\mathrm{ET}_{\mathrm{c}}$ maps showed low $\mathrm{ET}_{\mathrm{c}}$ values $\left(2.0 \mathrm{~mm}\right.$ day $^{-1}$ ) (light green color) at initial stage and high $\mathrm{ET}_{\mathrm{c}}$ values $\left(8.0 \mathrm{~mm} \mathrm{day}^{-1}\right)($ red color) at mid-season stage. These two seasons were characterized because in the initial stage crop needs smaller water requirements, whereas in the mid-season crop needs higher water requirements, as we can see in the next section. The $\mathrm{ET}_{\mathrm{c}}$ maps created in this study are in agreement with other researchers; for example, in $[2,4,58,59]$, they generated $\mathrm{ET}_{\mathrm{c}}$ maps using $K_{\mathrm{c}}$ derived from remote sensing-based vegetation 

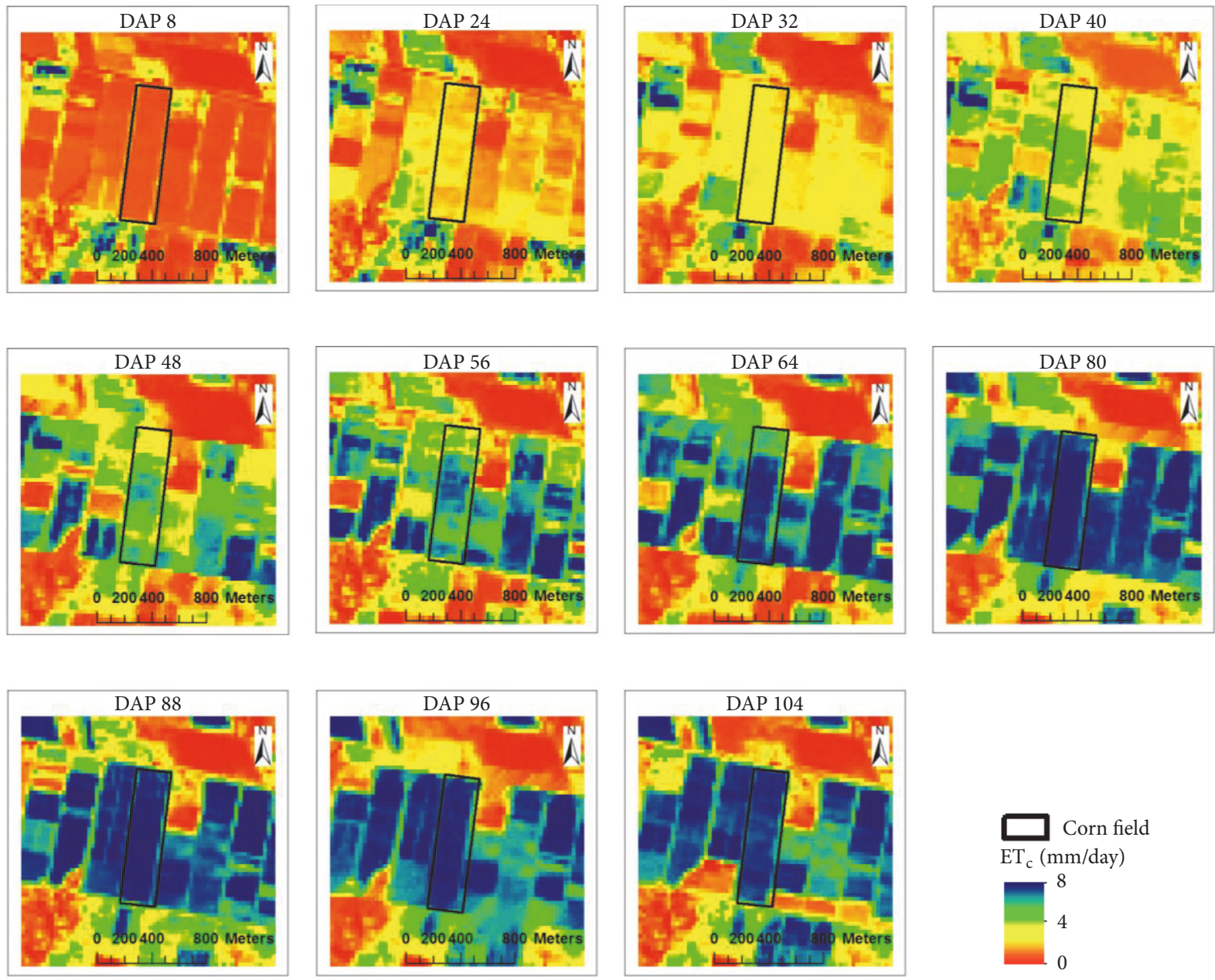

FIGURE 10: $\mathrm{ET}_{\mathrm{c}}$ maps at a field scale (e.g., silage corn) generated with ERDAS Imagine Software (Model Maker) and ArcGIS version 10.3.1 using Landsat 7 and Landsat 8 satellite images for the 2014 growing season. The red, light green, and dark blue colors within the corn field (black rectangle) indicate low, medium, and high $\mathrm{ET}_{\mathrm{c}}$ values.

indices. Other researchers reported that $K_{c}$ derived from canopy reflectance based vegetation index had the potential to estimate crop evapotranspiration at regional and field scales, for example, in $[17,18,29,55,60,61]$.

3.5. ET $T_{c}$ Maps at a Field Scale. $\mathrm{ET}_{\mathrm{c}}$ maps at filed scale help to explain the variability of crop water requirements during the growing season as shown in Figure 10. These images at a field scale level show the corresponding $\mathrm{ET}_{\mathrm{c}}$ values according to each growth stage; this indicates that each stage requires different amount of water throughout the season. For example, minimum water requirements $\left(2.0 \mathrm{~mm} \mathrm{day}^{-1}\right)$ are needed at the initial stage, whereas maximum water requirements are needed at mid-season stage $\left(8.0 \mathrm{~mm} \mathrm{day}^{-1}\right)$. Understating different crop growth stages and applying the accurate amount of volumetric water, farmers can improve their irrigation scheduling, improve water management, and enhance irrigation water sustainability.

Similar $\mathrm{ET}_{\mathrm{c}}$ maps at a field scale for agricultural crops including corn were reported by Farg et al. [32], Zipper and Loheide [62], and Senay et al. [63], they reported minimum and maximum $\mathrm{ET}_{\mathrm{c}}$ values at different crop growth stages, where the higher evapotranspiration rates were found at the mid-season growth stage and lowest evapotranspiration rates were found at early growth stage.

3.6. Comparison between $E T_{r}$ and $E T_{c}$. The $\mathrm{ET}_{\mathrm{r}}$ values were taken directly from a local weather station, while $\mathrm{ET}_{\mathrm{c}}$ values were derived from $\mathrm{ET}_{\mathrm{c}}$ maps. Figure 11 shows the comparison between $\mathrm{ET}_{\mathrm{r}}$ and $\mathrm{ET}_{\mathrm{c}}$ for 214 growing season. This figure illustrated that the daily $\mathrm{ET}_{\mathrm{r}}$ values were higher than the daily $\mathrm{ET}_{\mathrm{c}}$ outputs at the beginning of the growing season, but similar values were recorded at mid-season stage. In early stage (DAP 1-20) the $\mathrm{ET}_{\mathrm{r}}$ values were around $6.0 \mathrm{~mm} \mathrm{day}^{-1}$, while the $\mathrm{ET}_{\mathrm{c}}$ values were around $2.0 \mathrm{~mm} \mathrm{day}^{-1}$. In development stage (DAP 20-55) the $\mathrm{ET}_{\mathrm{r}}$ values continue around $6 \mathrm{~mm} \mathrm{day}^{-1}$, while $\mathrm{ET}_{\mathrm{c}}$ values increase from 2 to $6 \mathrm{~mm} \mathrm{day}^{-1}$. In the midseason stage (DAP 55-95) both $\mathrm{ET}_{\mathrm{r}}$ and $\mathrm{ET}_{\mathrm{c}}$ values were very similar around $7.0 \mathrm{~mm} \mathrm{day}^{-1}$. At the end of the growing season (DAP 95-105) the $\mathrm{ET}_{\mathrm{r}}$ values were slightly greater than $\mathrm{ET}_{\mathrm{c}}$ values by $0.5 \mathrm{~mm} \mathrm{day}^{-1}$. From early to mid-development stage the $\mathrm{ET}_{\mathrm{c}}$ values were lower than $\mathrm{ET}_{\mathrm{r}}$ values, this means 


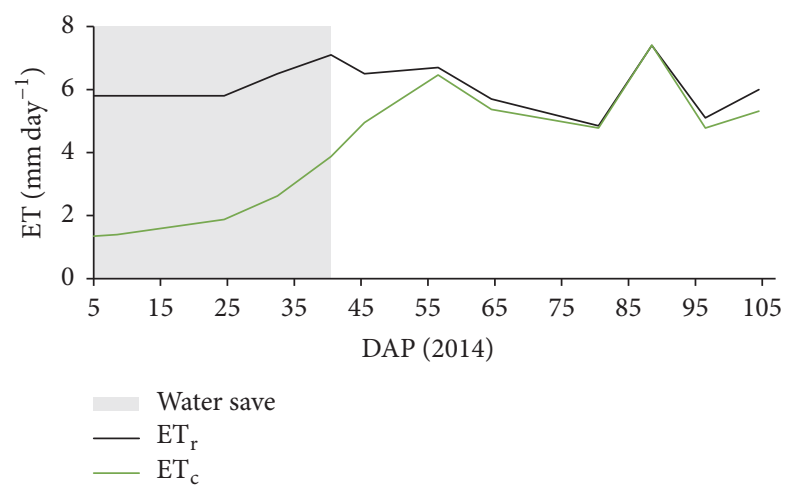

FIgURE 11: Comparison between $\mathrm{ET}_{\mathrm{r}}$ and $\mathrm{ET}_{\mathrm{c}}$ for 2014 growing season in northern Mexico. The grey wide column indicates the time interval where producers can save irrigation water.

that in those particular stages farmers can save irrigation water (grey wide column in the graph), because in those stages the crop needs small water requirements, due to the fact that the crop canopy is no yet fully developed. In short, the $\mathrm{ET}_{\mathrm{c}}$ values from $\mathrm{ET}_{\mathrm{c}}$ maps could be used by farmers in their irrigation scheduling programs because it shows when and how much water is required by the crop during different growth stages.

Reyes-González et al. [54] reported that the farmers should use $\mathrm{ET}_{\mathrm{c}}$ instead of $\mathrm{ET}_{\mathrm{r}}$ for irrigation scheduling in arid and semiarid region where irrigation water is scarce. USDANASS [64] reported that the farmers in the United States use four primary methods to determine when to irrigate: the first was visual observation of crop condition method (41\%), the second was the soil feel method (21\%), the third was personal calendar schedule method (11\%), and the fourth was daily crop evapotranspiration method (4\%). Methods for deciding when to irrigate need to be more accurate because of the competition for irrigation water increases and its value increases. Farmers must use scientific irrigation scheduling methods (e.g., ET method) instead of empirical methods (e.g., crop condition, feel of soil, and personal calendar) to save water and protect the environment. The ET method is based on climatic demands and is more accurate than empirical methods for irrigation scheduling [65]. ET maps and atmometers are methods to estimate crop water requirements with high accuracy [11].

\section{Conclusions}

The general objective of this study was to estimate crop evapotranspiration using satellite remote sensing-based vegetation index in northern Mexico.

The relationships between NDVI derived from Landsat images and tabulated $K_{\mathrm{c}}$ obtained from ASCE Manual 70 (Appendix E) were established for four growing seasons. These empirical linear regression equations were used to generate a single linear regression equation.

$\mathrm{ET}_{\mathrm{c}}$ maps were created as an output of $K_{\mathrm{c}}$ maps multiplied by $\mathrm{ET}_{\mathrm{r}}$ values. The $\mathrm{ET}_{\mathrm{c}}$ values ranged from 1.40 to $7.41 \mathrm{~mm}$ day $^{-1}$ during the period of study. The results showed that $\mathrm{ET}_{\mathrm{c}}$ values were low at initial and early development stages, while $\mathrm{ET}_{\mathrm{c}}$ values were high during mid-season and harvest stages. Daily $\mathrm{ET}_{\mathrm{c}}$ maps helped to explain the variability of crop water use throughout the growing season.

Farmers in northern Mexico region use empirical methods in their irrigation scheduling methods. The results indicate that farmers could reduce their seasonal water application amounts by $18 \%$ just by using $\mathrm{ET}_{\mathrm{c}}$ appropriately in their irrigation scheduling methods.

The information generated in this study is essential for irrigation scheduling because it shows when and how much water is required by the crop during different crop growth stages.

According to our results we can conclude that $\mathrm{ET}_{\mathrm{c}}$ maps developed from remotely sensed multispectral vegetation indices are a useful tool for quantifying accurate crop water consumption or crop evapotranspiration at regional and field scales.

\section{Conflicts of Interest}

The authors declare that they have no conflicts of interest.

\section{Acknowledgments}

The first author would like to acknowledge the National Council for Science and Technology of Mexico (CONACYT) and the National Institute of Forestry, Agriculture, and Livestock Research (INIFAP) for funding his doctoral scholarship. Additional funding is provided by the South Dakota Agricultural Experiment Station and the South Dakota Water Resources Institute.

\section{References}

[1] D. F. Heermann and K. H. Solomon, "Efficiency and uniformity," Design and operation of farm irrigation systems, vol. 5, pp. 108-119, 2007.

[2] N. K. Gontia and K. N. Tiwari, "Estimation of crop coefficient and evapotranspiration of wheat (Triticum aestivum) in an irrigation command using remote sensing and GIS," Water Resources Management, vol. 24, no. 7, pp. 1399-1414, 2010.

[3] H. V. Parmar and N. K. Gontia, "Remote sensing based vegetation indices and crop coefficient relationship for estimation of crop evapotranspiration in Ozat-II canal command," Journal of Agrometeorology, vol. 18, no. 1, pp. 137-139, 2016.

[4] E. Adamala, Y. A. Rajwade, and Y. V. K. Reddy, "Estimation of wheat crop evapotranspiration using NDVI vegetation index," Journal of Applied and Natural Science, vol. 8, no. 1, pp. 159-166, 2016.

[5] R. G. Allen, L. S. Pereira, D. Raes, and M. Smith, Crop evapotranspiration: Guide-lines for computing crop requirements, Irrigation and Drainage Paper no. 56, FAO, Rome, Italy, 1998.

[6] R. G. Allen, A. J. Clemmens, C. M. Burt, K. Solomon, and T. O'Halloran, "Prediction accuracy for projectwide evapotranspiration using crop coefficients and reference evapotranspiration," Journal of Irrigation and Drainage Engineering, vol. 131, no. 1, pp. 24-36, 2005.

[7] M. E. Jensen and R. G. Allen, Evaporation, Evapotranspiration, and Irrigation Water Requirements, ASCE Manuals and reports 
on Engineering Practice: no 70, American Society of Civil Engineers, Reston, Virginia, USA, 2nd edition, 2016.

[8] W. G. M. Bastiaanssen, E. J. M. Noordman, H. Pelgrum, G. Davids, B. P. Thoreson, and R. G. Allen, "SEBAL model with remotely sensed data to improve water-resources management under actual field conditions," Journal of Irrigation and Drainage Engineering, vol. 131, no. 1, pp. 85-93, 2005.

[9] R. Allen, M. Tasumi, and R. Trezza, "Satellite-based energy balance for mapping evapotranspiration with internalized calibration (METRIC) - model," Journal of Irrigation and Drainage Engineering, vol. 133, no. 4, pp. 380-394, 2007.

[10] J. Kjaersgaard, R. Allen, and A. Irmak, "Improved methods for estimating monthly and growing season ET using METRIC applied to moderate resolution satellite imagery," Hydrological Processes, vol. 25, no. 26, pp. 4028-4036, 2011.

[11] A. Reyes-González, J. Kjaersgaard, T. Trooien, C. Hay, and L. Ahiablame, "Comparative Analysis of METRIC Model and Atmometer Methods for Estimating Actual Evapotranspiration," International Journal of Agronomy, vol. 2017, pp. 1-16, 2017.

[12] C. M. U. Neale, H. Jayanthi, and J. L. Wright, "Irrigation water management using high resolution airborne remote sensing," Irrigation and Drainage Systems, vol. 19, no. 3-4, pp. 321-336, 2005.

[13] E. P. Glenn, C. M. U. Neale, D. J. Hunsaker, and P. L. Nagler, "Vegetation index-based crop coefficients to estimate evapotranspiration by remote sensing in agricultural and natural ecosystems," Hydrological Processes, vol. 25, no. 26, pp. 40504062, 2011.

[14] J. W. Rouse, R. H. Haas, J. A. Schell, and D. W. Deering, "Monitoring vegetation systems in the Great Plains with ERTS," in Third ERTS symposium, pp. 309-317, NASA, Washington DC, USA, 10-14 December 1973.

[15] E. P. Glenn, P. L. Nagler, and A. R. Huete, "Vegetation Index Methods for Estimating Evapotranspiration by Remote Sensing," Surveys in Geophysics, vol. 31, no. 6, pp. 531-555, 2010.

[16] C. Romero-Trigueros, P. A. Nortes, J. J. Alarcón et al., "Effects of saline reclaimed waters and deficit irrigation on Citrus physiology assessed by UAV remote sensing," Agricultural Water Management, vol. 183, pp. 60-69, 2017.

[17] C. Toureiro, R. Serralheiro, S. Shahidian, and A. Sousa, "Irrigation management with remote sensing: evaluating irrigation requirement for maize under Mediterranean climate condition," Agricultural Water Management, vol. 184, pp. 211-220, 2017.

[18] H. Lei and D. Yang, "Combining the crop coefficient of winter wheat and summer maize with a remotely sensed vegetation index for estimating evapotranspiration in the North China plain," Journal of Hydrologic Engineering, vol. 19, no. 1, pp. 243251, 2014.

[19] E. G. Kullberg, K. C. DeJonge, and J. L. Chávez, "Evaluation of thermal remote sensing indices to estimate crop evapotranspiration coefficients," Agricultural Water Management, vol. 179, pp. 64-73, 2017.

[20] C. M. U. Neale, W. C. Bausch, and D. F. Herman, "Development of reflectance-based crop coefficient for corn," Transactions of the ASAE, vol. 32, no. 6, pp. 1891-1899, 1989.

[21] W. C. Bausch, "Remote sensing of crop coefficients for improving the irrigation scheduling of corn," Agricultural Water Management, vol. 27, no. 1, pp. 55-68, 1995.

[22] J. Garatuza-Payan, A. Tamayo, C. Watts, and J. Rodriguez, "Estimating large area wheat evapotranspiration from remote sensing data," in Proceedings of the IGARSS 2003. 2003 IEEE
International Geoscience and Remote Sensing Symposium., pp. 380-382, Toulouse, France.

[23] D. J. Hunsaker, P. J. Pinter Jr., E. M. Barnes, and B. A. Kimball, "Estimating cotton evapotranspiration crop coefficients with a multispectral vegetation index," Irrigation Science, vol. 22, no. 2, pp. 95-104, 2003.

[24] M. Tasumi, R. G. Allen, R. Trezza, and J. L. Wright, "Satellitebased energy balance to assess within-population variance of crop coefficient curves," Journal of Irrigation and Drainage Engineering, vol. 131, no. 1, pp. 94-109, 2005.

[25] B. Duchemin, R. Hadria, S. Erraki et al., "Monitoring wheat phenology and irrigation in Central Morocco: On the use of relationships between evapotranspiration, crops coefficients, leaf area index and remotely-sensed vegetation indices," Agricultural Water Management, vol. 79, no. 1, pp. 1-27, 2006.

[26] H. Jayanthi, C. M. U. Neale, and J. L. Wright, "Development and validation of canopy reflectance-based crop coefficient for potato," Agricultural Water Management, vol. 88, no. 1-3, pp. 235-246, 2007.

[27] T. J. Trout, "Remote sensing of canopy cover in horticultural crops," HortScience, vol. 43, no. 2, pp. 333-337, 2008.

[28] M. P. González-Dugo and L. Mateos, "Spectral vegetation indices for benchmarking water productivity of irrigated cotton and sugarbeet crops," Agricultural Water Management, vol. 95, no. 1, pp. 48-58, 2008.

[29] I. Campos, C. M. U. Neale, A. Calera, C. Balbontín, and J. González-Piqueras, "Assessing satellite-based basal crop coefficients for irrigated grapes (Vitis vinifera L.)," Agricultural Water Management, vol. 98, no. 1, pp. 45-54, 2010.

[30] B. Kamble, A. Kilic, and K. Hubbard, "Estimating crop coefficients using remote sensing-based vegetation index," Remote Sensing, vol. 5, no. 4, pp. 1588-1602, 2013.

[31] A. Reyes-González, C. Hay, J. Kjaersgaard, and C. M. U. Neale, "Use of remote sensing to generate crop coefficient and estimate actual crop evapotranspiration," in ASABE Annual international meeting, New Orleans LA, USA, 2015.

[32] E. Farg, S. M. Arafat, M. S. Abd El-Wahed, and A. M. El-Gindy, "Estimation of Evapotranspiration ETc and Crop Coefficient Kc of Wheat, in south Nile Delta of Egypt Using integrated FAO-56 approach and remote sensing data," Egyptian Journal of Remote Sensing and Space Science, vol. 15, no. 1, pp. 83-89, 2012.

[33] S. Vanino, G. Pulighe, P. Nino, C. de Michele, S. F. Bolognesi, and G. D'Urso, "Estimation of evapotranspiration and crop coefficients of tendone vineyards using multi-sensor remote sensing data in a mediterranean environment," Remote Sensing, vol. 7, no. 11, pp. 14708-14730, 2015.

[34] H. Zhang, R. G. Anderson, and D. Wang, "Satellite-based crop coefficient and regional water use estimates for Hawaiian sugarcane," Field Crops Research, vol. 180, pp. 143-154, 2015.

[35] SAGARPA, "Resumen Sector Agropecuario en la Región Lagunera," Publicación especial el Siglo de Torreón, p. 24, 2016.

[36] R. P. Cano and M. M. C. Medina, "Tecnologia de produccion de nogal pecanero," Libro Tecnico, vol. no. 3, p. 220, 2002.

[37] G. Levin, G. A. Cruz, D. Garcia, C. Garces-Restrepo, and S. Johnson, Performance of two transferred modules in the lagunera region: water relations, Research Report 23, vol. 23, nternational Water Management Institute, Colombo, Sri Lanka, 1998.

[38] W. C. Bausch, "Soil background effects on reflectance-based crop coefficients for corn," Remote Sensing of Environment, vol. 46, no. 2, pp. 213-222, 1993. 
[39] A. Bannari, D. Morin, F. Bonn, and A. R. Huete, "A review of vegetation indices," International Journal of Remote Sensing, vol. 13, no. 1-2, pp. 95-120, 1995.

[40] A. Reyes-González, U. Figueroa, D. G. Reta, J. I. Sanchez, and J. G. Martinez, Estimación de la evapotranspiración actual utilizando sensors remotos y mediciones in situ, En la Comarca Lagunera, Mexico, 2012.

[41] ASCE-EWRI, “The ASCE Standardized Reference Evapotranspiration Equation. Report of the ASCE-EWRI Task Committee on Standardization of Reference Evapotranspiration," Tech. Rep., ASCE, Reston, VA, USA, 2005.

[42] T. J. Jackson, D. Chen, M. Cosh et al., "Vegetation water content mapping using Landsat data derived normalized difference water index for corn and soybeans," Remote Sensing of Environment, vol. 92, no. 4, pp. 475-482, 2004.

[43] P.-Y. Chen, G. Fedosejevs, M. Tiscareño-López, and J. G. Arnold, "Assessment of MODIS-EVI, MODIS-NDVI and VEGETATION-NDVI composite data using agricultural measurements: An example at corn fields in western Mexico," Environmental Modeling \& Assessment, vol. 119, no. 1-3, pp. 69$82,2006$.

[44] W. E. Thomason, S. B. Phillips, and F. D. Raymond, "Defining useful limits for spectral reflectance measures in corn," Journal of Plant Nutrition, vol. 30, no. 8, pp. 1263-1277, 2007.

[45] R. K. Singh and A. Irmak, "Estimation of crop coefficients using satellite remote sensing," Journal of Irrigation and Drainage Engineering, vol. 135, no. 5, pp. 597-608, 2009.

[46] C. H. W. de Souza, E. Mercante, J. A. Johann, R. A. C. Lamparelli, and M. A. Uribe-Opazo, "Mapping and discrimination of soya bean and corn crops using spectro-temporal profiles of vegetation indices," International Journal of Remote Sensing, vol. 36, no. 7, pp. 1809-1824, 2015.

[47] F. Gao, M. C. Anderson, X. Zhang et al., “Toward mapping crop progress at field scales through fusion of Landsat and MODIS imagery," Remote Sensing of Environment, vol. 188, pp. 9-25, 2017.

[48] N. Flood, "Continuity of reflectance data between landsat-7 ETM+ and landsat-8 OLI, for both top-of-atmosphere and surface reflectance: a study in the australian landscape," Remote Sensing, vol. 6, no. 9, pp. 7952-7970, 2014.

[49] Y. Ke, J. Im, J. Lee, H. Gong, and Y. Ryu, "Characteristics of Landsat 8 OLI-derived NDVI by comparison with multiple satellite sensors and in-situ observations," Remote Sensing of Environment, vol. 164, pp. 298-313, 2015.

[50] D. P. Roy, V. Kovalskyy, H. K. Zhang et al., "Characterization of Landsat-7 to Landsat- 8 reflective wavelength and normalized difference vegetation index continuity," Remote Sensing of Environment, vol. 185, pp. 57-70, 2016.

[51] D. P. Roy, M. A. Wulder, T. R. Loveland et al., "Landsat8: science and product vision for terrestrial global change research," Remote Sensing of Environment, vol. 145, pp. 154-172, 2014.

[52] C. E. Holden and C. E. Woodcock, "An analysis of Landsat 7 and Landsat 8 underflight data and the implications for time series investigations," Remote Sensing of Environment, vol. 185, pp. 1636, 2016.

[53] J. Rocha, A. Perdigão, R. Melo, and C. Henriques, "Remote sensing based crop coefficients for water management in agriculture,Chapter 8," INTECH, pp. 167-192, 2012.

[54] A. Reyes-González, T. Trooien, J. Kjaersgaard, C. Hay, and D. G. Reta-Sánchez, "Development of crop coefficients using remote sensing-based vegetation index and growing degree days," in Proceedings of the ASABE Annual International Meeting, Orlando, Fla, USA, July 2016.

[55] E. B. Rafn, B. Contor, and D. P. Ames, "Evaluation of a method for estimating irrigated crop-evapotranspiration coefficients from remotely sensed data in Idaho," Journal of Irrigation and Drainage Engineering, vol. 134, no. 6, pp. 722-729, 2008.

[56] R. G. Steel and J. H. Torrie, Principles and procedures of statistic: a biometrical approach, McGraw-Hill, NY, USA, 1980.

[57] A. Irmak, I. Ratcliffe, P. Ranade et al., "Estimation of land surface evapotranspiration with a satellite remote sensing procedure," Great Plains Research, vol. 21, no. 1, pp. 73-88, 2011.

[58] L. Rossato, R. C. S. Alvalá, N. J. Ferreira, and J. Tomasella, "Evapotranspiration estimation in the Brazil using NDVI data," in Proceedings of the Remote Sensing for Agriculture, Ecosystems, and Hydrology VII, Belgium, September 2005.

[59] M. Mahour, V. Tolpekin, A. Stein, and A. Sharifi, "A comparison of two downscaling procedures to increase the spatial resolution of mapping actual evapotranspiration," ISPRS Journal of Photogrammetry and Remote Sensing, vol. 126, pp. 56-67, 2017.

[60] M. P. Gonzalez-Dugo, C. M. U. Neale, L. Mateos et al., "A comparison of operational remote sensing-based models for estimating crop evapotranspiration," Agricultural and Forest Meteorology, vol. 149, no. 11, pp. 1843-1853, 2009.

[61] R. S. Murray, P. L. Nagler, K. Morino, and E. P. Glenn, “An empirical algorithm for estimating agricultural and riparian evapotranspiration using MODIS enhanced vegetation index and ground measurements of ET. II. application to the lower Colorado river, U.S.," Remote Sensing, vol. 1, no. 4, pp. 1125-1138, 2009.

[62] S. C. Zipper and S. P. Loheide, "Using evapotranspiration to assess drought sensitivity on a subfield scale with HRMET, a high resolution surface energy balance model," Agricultural and Forest Meteorology, vol. 197, pp. 91-102, 2014.

[63] G. B. Senay, M. Friedrichs, R. K. Singh, and N. M. Velpuri, "Evaluating Landsat 8 evapotranspiration for water use mapping in the Colorado River Basin," Remote Sensing of Environment, vol. 185, pp. 171-185, 2016.

[64] USDA-NASS, Farm and Ranch Irrigation Survey, Table 22Methods used in deciding when to irrigate USDA National Agricultural Statistics Service, 2013.

[65] J. C. Henggeler, M. D. Dukes, and B. Q. Mecham, "Chapter 13 Irrigation Scheduling," in Irrigation, L. E. Stetson and B. Q. Mecham, Eds., pp. 491-564, Falls Church, VA, USA, 6th edition, 2011. 

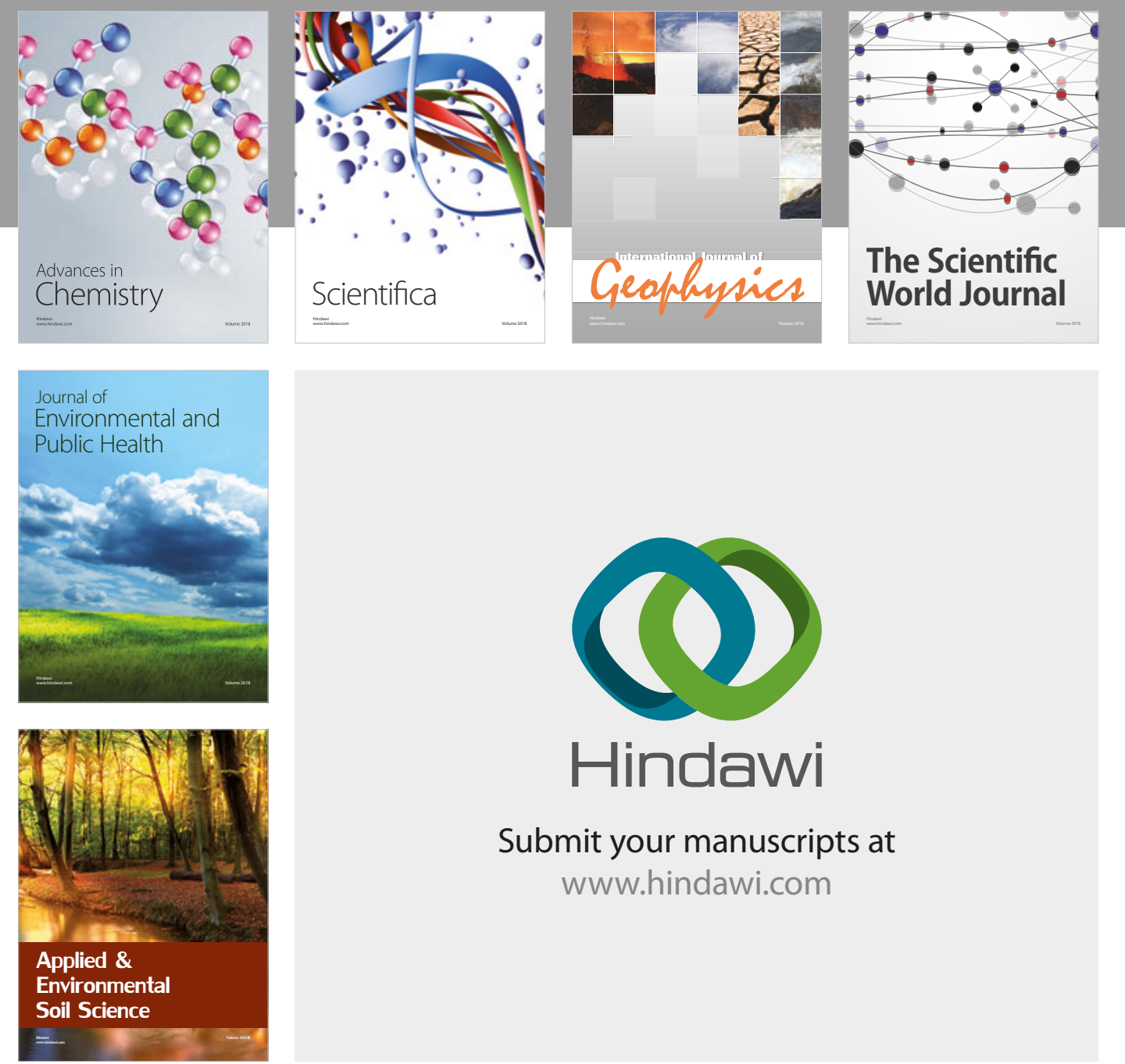

The Scientific

\section{World Journal}
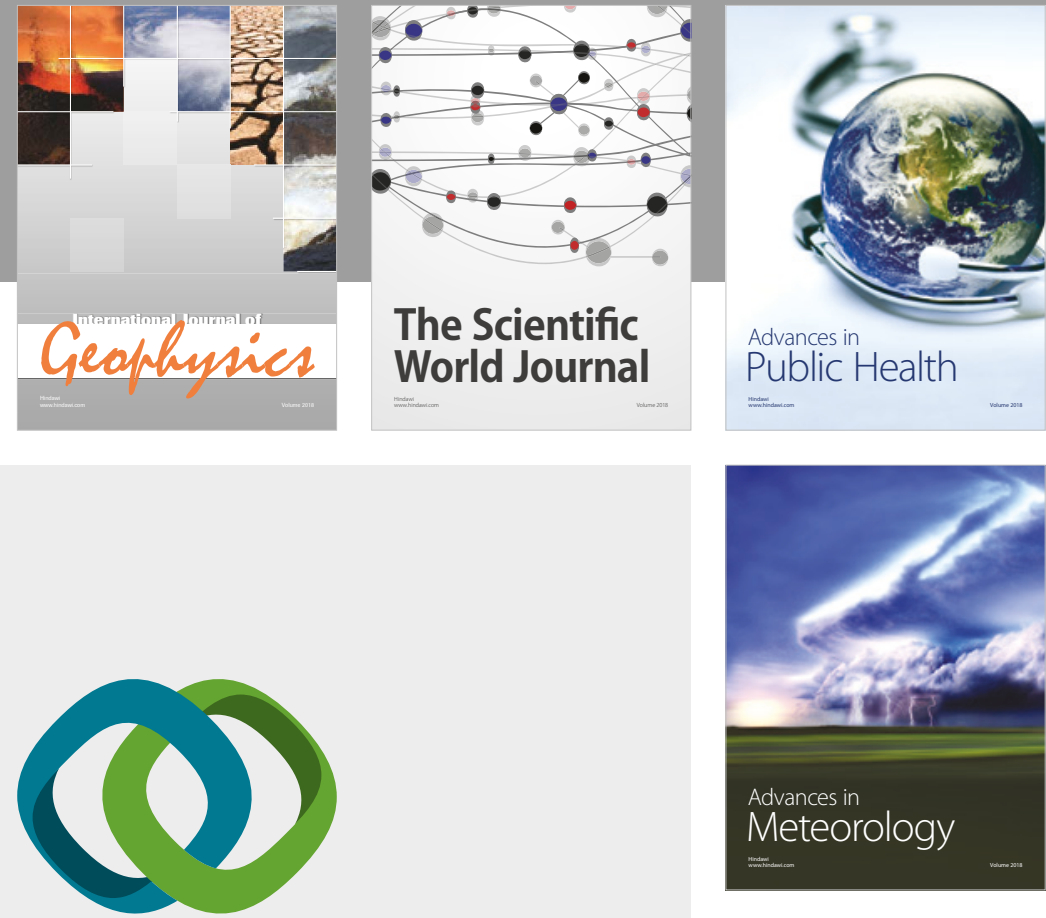

Advan

Public Health

\section{Hindawi}

Submit your manuscripts at

www.hindawi.com
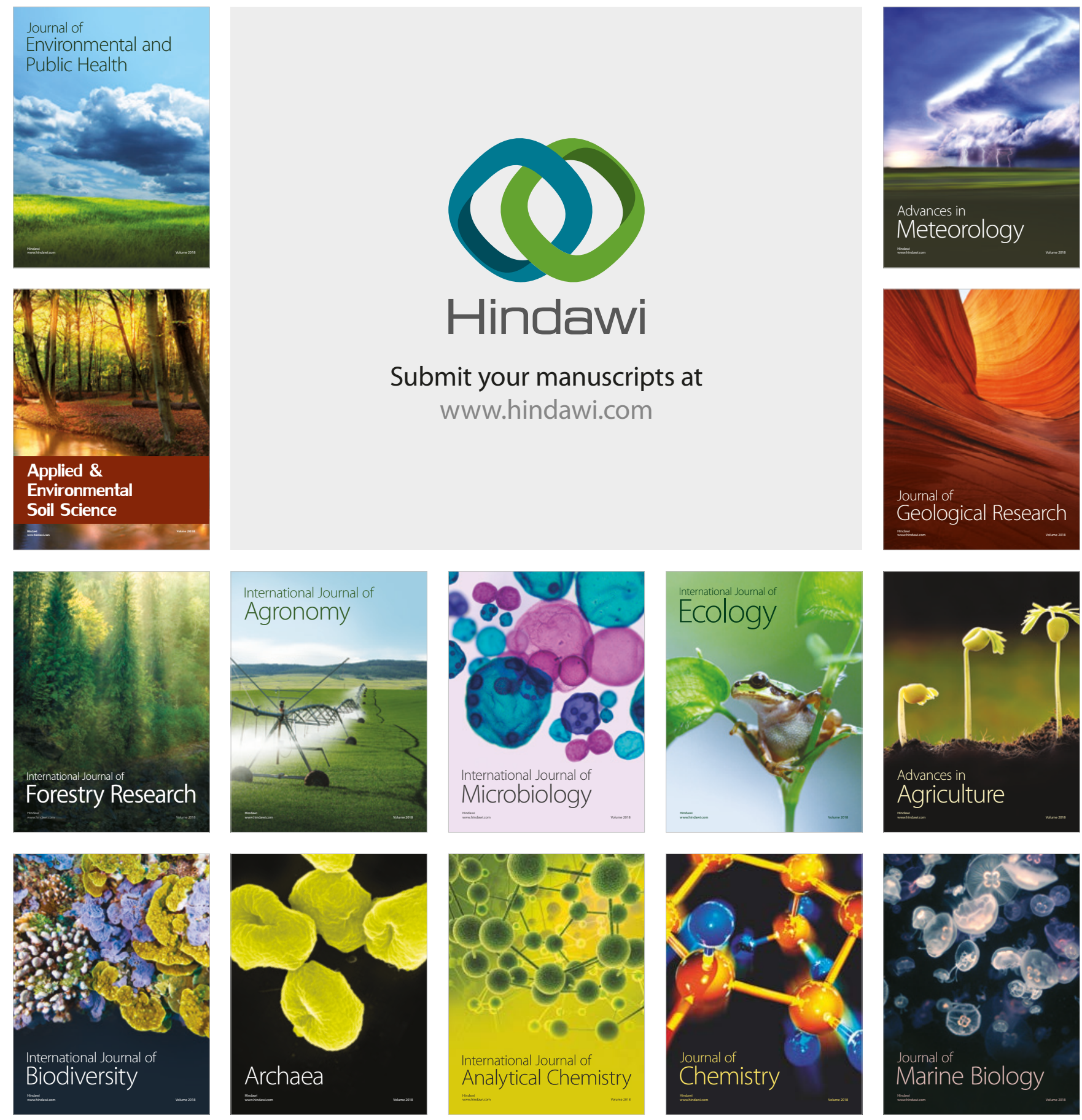